\title{
PEMANFAATAN PUPUK ORGANIK CAIR REBUNG BAMBU U NTUK PERTUMBUHAN KANGKUNG SECARA HIDROPONIK
}

\author{
Faridha Angraeni ${ }^{1}$, Pauline Destinugrainy Kasi ${ }^{1}$, Suaedi ${ }^{*}$, Saiful Sanmas ${ }^{3}$, \\ ${ }^{1}$ Program Studi Biologi, Fakultas Sains, Universitas Cokroaminoto Palopo, Palopo, \\ 91921, Indonesia, E-mail: pauline@ uncp.ac.id \\ ${ }^{2}$ Program Studi Agribisnis, Fakultas Pertanian, Universitas Cokroaminoto Palopo, \\ Palopo, 91921, Indonesia
}

\begin{abstract}
Abstrak: Pupuk Organik Cair (POC) merupakan teknologi untuk menunjang perkembangan pertanian ramah lingkungan, menekan penggunaan pupuk kimia dan menghasilkan bahan yang bebas bahan kimia sehingga sehat dan bersih untuk dikonsumsi. Penelitian ini bertujuan untuk mengetahui bagaimana pengaruh pemberian POC rebung bambu terhadap pertumbuhan tanaman kangkung (Ipomea reptans Poir) dan untuk mengetahui konsentrasi POC rebung bambu yang memberikan pengaruh terbaik pada pertumbuhan tanaman kangkung (Ipomea reptans Poir). Penelitian ini dilaksanakan pada bulan Januari sampai dengan Maret 2017 di Green House Fakultas Sains Universitas Cokroaminoto Palopo. Penelitian ini menggunakan Rancangan Acak Lengkap (RAL) yang terdiri dari 5 perlakuan $(\mathrm{P} 0=$ Air $200 \mathrm{ml}$ sebagai Kontrol, $\mathrm{P} 1=$ POC $50 \mathrm{ml}+$ Air $150 \mathrm{ml}, \mathrm{P} 2=$ POC $100 \mathrm{ml}+$ Air $100 \mathrm{ml}$, P3 = POC $150 \mathrm{ml}+$ Air 50 $\mathrm{ml}$ dan $\mathrm{P} 4=$ POC $200 \mathrm{ml}$ ) masing-masing dengan 3 kali ulangan. Hasil uji kandungan NPK pada POC rebung bambu menunjukkan kandungan $\mathrm{N}$-total sebesar $0,72 \%$, kandungan $\mathrm{P}_{2} \mathrm{O}_{5}$ sebesar $0,04 \%$ dan $\mathrm{K}_{2} \mathrm{O}$ sebesar $0,12 \%$. Hasil penelitian menunjukkan bahwa pemberian pupuk organik cair yang efektif dan terbaik terdapat pada perlakuan P4 (Pupuk Organik Cair $200 \mathrm{ml}$ ) dengan rata-rata tinggi tanaman kangkung 27,67 cm, jumlah daun yaitu sekitar 36 helai dan warna daun yaitu 5,00 (menurut Bagan Warna Daun).
\end{abstract}

\section{Kata Kunci: Pupuk Organik Cair, Rebung Bambu, Hidroponik}

Abstract: Liquid Organic Fertilizer (LOF) is a technology to support the development of eco-friendly agriculture, suppress the use of chemical fertilizers and produce chemicals free material so healthy and clean for consumption. This study amis to know how the effect of bamboo shoot LOF for the growth of kangkung (Ipomea reptans Poir) and to find out the concentration of LOF give the best effect for the growth of the Ipomea reptans Poir. The research was conducted from January to March 2017 at green house in Faculty of Science, Universitas Cokroaminoto Palopo. This study used Completely Randomized Design (CRD) consisting of 5 treatments $(\mathrm{P} 0=$ Water $200 \mathrm{ml}$ as Control, P1 = $50 \mathrm{ml} \mathrm{LOF}+$ Water $150 \mathrm{ml}, \mathrm{P} 2=100 \mathrm{ml} \mathrm{LOF}+$ Water $100 \mathrm{ml}, \mathrm{P} 3=$ LOF $150 \mathrm{ml}+$ Water $50 \mathrm{ml}$ and $\mathrm{P} 4=$ LOF $200 \mathrm{ml}$ ) with 3 replications for each treatment respectively. The result of NPK content test on bamboo shoot POC showed $0.72 \%$ Total-N. $0.04 \% \mathrm{P}_{2} \mathrm{O}_{5}$, and $0.12 \% \mathrm{~K}_{2} \mathrm{O}$. The results of treatments showed that the effective and best LOF was found in the treatment of P4 (LOF $200 \mathrm{ml}$ ), with the

BIOLOGI SEL (VOL 7 NO 1 EDISI JAN-JUL 2018 ISSN 2252-858X/E-ISSN 2541-1225) PAGE 42 
average height of kangkung $27.67 \mathrm{~cm}$, the number of leaves is about 36 pieces for each plants and leaf color is 5.00 (according to leaf color chart).

\section{Keywords: Liquid Organic Fertilizer, Bamboo Shoots, Hydroponics}

Kangkung darat (Ipomoea reptans Poir) merupakan sayuran yang bernilai ekonomi dan persebarannya cukup meluas pesat di daerah Asia Tenggara. Beberapa negara yang merintis pembudidayaan tanaman kangkung secara intensif dan komersial adalah Taiwan, Thailand, Filipina, dan Indonesia. Kangkung darat umumnya dikonsumsi oleh masyarakat Indonesia dan dapat menjadi salah satu menu di rumahrumah makan (Rukmana, 1994). Produksi kangkung di Indonesia dapat mencapai 50.000-60.000 kg per hektar (Harjadi \& Suketi, 1999). Lahan $1 / 4$ ha yang ditanami kangkung dalam sekali tanam menghabiskan $5 \mathrm{~kg}$ benih kangkung namun menghasilkan produk yang masih kurang dibanding tanaman lainnya.

Dari aspek sosial dan ekonomi, tanaman kangkung darat memiliki prospek yang cukup baik jika dikembangkan ke arah agribisnis. Kangkung darat menempati urutan ke-14 dari 18 jenis sayur di Indonesia (Sawasemariai, 2012). Meski harga sayuran kangkung relatif lebih murah, namun bila dibudidayakan secara intensif dan berorientasi ke arah agribisnis akan memberikan keuntungan yang cukup besar bagi petani. Peluang pemasaran kangkung makin luas karena tidak hanya dapat dijual di pasar-pasar lokal di daerah, tetapi juga telah banyak dipesan oleh pasar-pasar swalayan. Dengan masuknya sayuran kangkung ke pasar-pasar swalayan akan menaikkan harga jual sayuran ini (Taufik, 2012). Dalam mengembangkan hasil pertanian kangkung darat (Ipomea reptans Poir) dengan melihat banyaknya lahan yang tidak dipakai oleh masyarakat untuk lahan pertanian, maka saat ini ada cara lain untuk memanfaatkan lahan sempit sebagai usaha untuk mengembangkan hasil pertanian, yaitu dengan cara bercocok tanam secara hidroponik.

Hidroponik merupakan sistem bercocok tanam yang menggunakan media selain tanah (Mas'ud, 2009). Sehingga sistem bercocok tanam secara hidroponik dapat memanfaatkan lahan yang sempit. Pertanian dengan menggunakan sistem hidroponik memang tidak memerlukan lahan yang luas dalam pelaksanaannya, tetapi dalam bisnis pertanian hidroponik hanya layak dipertimbangkan mengingat dapat dilakukan di pekarangan rumah, atap rumah maupun lahan lainnya. Kelebihan dari bercocok tanam secara hidroponik yaitu : penanaman dapat dilakukan tanpa tergantung musim, memiliki kualitas lebih baik, kebersihan lebih terjamin, pemakaian pupuk lebih efisien, perawatan lebih praktis, dan tidak banyak membutuhkan tenaga kerja. Budidaya hidroponik terdiri dari dua sistem yaitu sistem hidroponik substrat dan non substrat. Salah satu sistem yang terdapat dalam budidaya hidroponik adalah sistem sumbu (wick system) (Lingga, 2005). 
Upaya peningkatan produktivitas tanaman kangkung dengan pemupukan secara umum telah banyak dilakukan meskipun hasilnya belum cukup memuaskan. Pemakaian pupuk organik cair dinilai dapat secara cepat mengatasi kekurangan unsur hara dan mampu menyediakan hara secara cepat dan merupakan teknologi untuk menunjang perkembangan pertanian ramah lingkungan, menekan penggunaan pupuk kimia dan pestisida dengan sistem alami yang dapat meningkatkan produktivitas tanah, mengurangi biaya produksi dan menghasilkan bahan yang bebas bahan kimia sehingga sehat dan bersih untuk dikonsumsi.

Salah satu alternatif bahan dasar pupuk organik cair dapat berasal dari rebung bambu. Rebung bambu disebut juga trubus bambu atau tunas bambu merupakan kuncup bambu muda yang muncul dari dalam tanah yang berasal dari akar rhizoma maupun buku-bukunya. Rebung dapat dimanfaatkan sebagai bahan pangan yang tergolong kedalam jenis sayur-sayuran. Tidak semua jenis bambu dapat dimanfaatkan rebungnya untuk bahan pangan, karena rasanya yang pahit (Kencana, 1992). Tunas muda ini dapat dijadikan sebagai bahan dasar pembuatan pupuk organik cair (POC). Menurut Erwin et al., (2012), larutan POC rebung bambu mempunyai kandungan $\mathrm{C}$ organik dan giberelin yang sangat tinggi sehingga mampu merangsang pertumbuhan tanaman. Selain itu larutan POC rebung bambu juga mengandung organisme yang penting untuk membantu pertumbuhan tanaman yaitu Azotobacter dan Azospirillum. Jika dilihat dari kandungannya, larutan POC rebung bambu bisa digunakan sebagai perangsang pertumbuhan pada fase vegetatif. Sehingga dalam penerapannya diharapkan bahwa pupuk organik cair (POC) dari rebung bambu dapat berpengaruh terhadap pertumbuhan tanaman kangkung (Ipomoea reptans Poir). Oleh karena itu, peneliti mencoba melakukan penelitian mengenai pengaruh konsentrasi pupuk organik cair dari rebung bambu terhadap pertumbuhan tanaman kangkung.

\section{METODE PENELITIAN}

\section{Bahan dan Alat}

Adapun alat yang digunakan pada penelitian ini adalah botol plastik bekas 15 buah, toples plastik, gelas ukur, blender, ember, gunting atau cutter, timbangan analitik, timbangan analog, lem lilin, selang $1 \mathrm{~m}$, panci, kompor, batang pengaduk, lakban, paranet, alat tulis, label dan kamera. Adapun bahan yang digunakan dalam penelitian ini adalah rebung bambu $1 \mathrm{~kg}$, arang sekam, sabut kelapa, kain flanel, EM4 1 botol, gula merah 2 ons, air cucian beras 3 liter, terasi, air sumur 5 liter dan benih kangkung darat.

\section{Prosedur Kerja}

Pembuatan pupuk organik cair (POC) dari rebung bambu dilakukan dengan cara rebung bambu sebanyak $1 \mathrm{~kg}$ dicacah, kemudian ditambahkan 2 liter air atau secukupnya dan direbus hingga matang. Setelah itu rebung yang telah direbus diblender dengan menambahkan air rebusan rebung sebanyak 1 liter. Rebung bambu yang telah

BIOLOGI SEL (VOL 7 NO 1 EDISI JAN-JUL 2018 ISSN 2252-858X/E-ISSN 2541-1225) PAGE 44 
diblender di masukkan ke dalam wadah atau ember, ditambahkan 0,2 kg gula merah , 3 liter air cucian, 1 botol EM4 dan terasi yang telah dihaluskan dan 5 liter air bersih. Selanjutnya semua bahan yang berada dalam satu wadah pembuatan POC diaduk hingga tercampur atau homogen setelah itu ditutup dengan rapat,. Fermentasi dilakukan selama 2 minggu hingga didapatkan POC rebung bambu. Kadar NPK dari POC rebung bambu dianalisis di Balai Pengkajian Teknologi Pertanian (BPTP) Maros. Setelah itu larutan POC siap digunakan.

\section{Penanaman dan Pengamatan}

Benih kangkung berumur 14 hari dengan jumlah daun dan tinggi yang seragam dijadikan sebagai objek penelitian. Benih kangkung ditanam pada medium hidroponik menggunakan media arang sekam dengan sistem sumbu (wick system) (Marlina et al., 2015). Sebagai pengganti nutrisi cair digunakan POC rebung bambu dalam berbagai konsentrasi perlakuan. Pengukuran tinggi tanaman, jumlah daun dan warna daun tanaman kangkung dilakukan setiap minggu seminggu selama 8 minggu. Pengukuran warna daun menggunakan bagan warna daun (BWD) (Gambar 1).

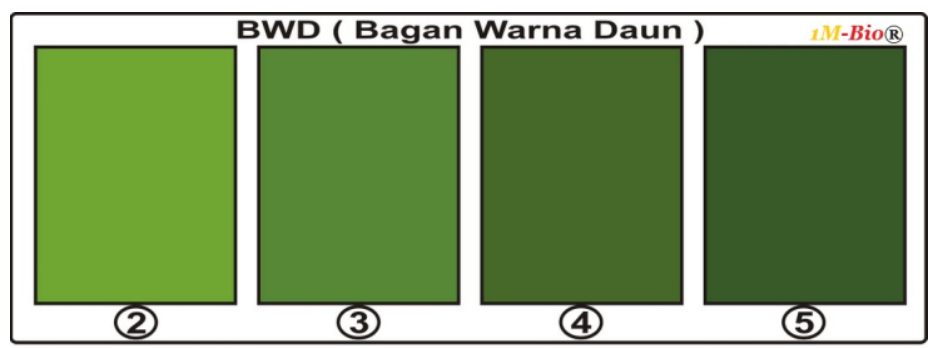

Gambar 1. Bagan Warna Daun dengan skala 2-5.

\section{Desain Penelitian}

Penelitian ini menggunakan Rancangan Acak Lengkap (RAL) dengan 5 perlakuan, ulangan $3 \mathrm{kali}$, dan setiap unit perlakuan terdiri dari satu tanaman, yang diberi simbol masing-masing P0, P1, P2, P3 dan P4. Sehingga secara keseluruhan terdapat 15 bibit tanaman kangkung. Adapun perlakuan yang digunakan dalam penelitian ini yaitu dosis Pupuk Organik Cair (POC) dari Rebung Bambu sebagai berikut : P0 = Air $200 \mathrm{ml}$ (sebagai kontrol); P1 = Pupuk Organik Cair $50 \mathrm{ml}+$ Air 150 ml; P2 = Pupuk Organik Cair 100 ml + Air 100 ml; P3 = Pupuk Organik Cair 150 ml + Air $50 \mathrm{ml}$, P4 = Pupuk Organik Cair $200 \mathrm{ml}$. Data kualitatif yang diperoleh dianalisis secara varians dalam bentuk uji $\mathrm{F} \alpha=0,05$ kemudian dilanjutkan dengan Uji Beda Nyata Terkecil (BNT) $\alpha=0,05 \geq \mathrm{F}$ tabel.

\section{HASIL DAN PEMBAHASAN}

\section{Uji Kandungan Unsur $\mathbf{N}$, P dan $K$}

Kandungan unsur hara yang dianalisis dalam POC rebung bambu adalah Ntotal, $\mathrm{P}_{2} \mathrm{O}_{5}$ dan $\mathrm{K}_{2} \mathrm{O}$ dengan menggunakan metode $\mathrm{Kjehdal} \mathrm{untuk} \mathrm{pengukuran} \mathrm{kadar}$ 
nitrogen dan kalium dan metode spketrofotometri untuk pengukuran kadar $\mathrm{P}_{2} \mathrm{O}_{5}$. Adapun hasil uji kandungan NPK dibandingkan dengan standar SNI 19-7030-2004 untuk Pupuk Organik Cair (Tabel 1).

Tabel 1. Hasil Pengujian Kadar NPK pada POC Rebung Bamboo

\begin{tabular}{cccc}
\hline No & Parameter & Hasil uji POC Rebung Bambu & Standar SNI 19-7030-2004 untuk POC \\
\hline 1 & N-total & $0,72 \%$ & $>0,40 \%$ \\
2 & $\mathrm{P}_{2} \mathrm{O}_{5}$ & $0,04 \%$ & $>0,10 \%$ \\
3 & $\mathrm{~K}_{2} \mathrm{O}$ & $0,12 \%$ & $>0,20 \%$ \\
\hline
\end{tabular}

Kandungan unsur nitrogen pada POC rebung bambu menunjukkan nilai yang lebih tinggi dibandingkan dengan unsure $\mathrm{P}$ dan $\mathrm{K}$. Kandungan Nitrogennya juga memenuhi standar SNI 19-7030-2004 untuk POC. Namun, kandungan P dan K belum memenuhi standar SNI. Tingginya protein dalam bahan organik rebung bambu dapat meningkatkan kandungan nitrogen pada pupuk organik cair yang dihasilkan, karena nitrogen merupakan hasil dari perombakan metabolisme protein. POC dengan kandungan nitrogen yang tinggi baik digunakan untuk memacu pertumbuhan tanaman.

\section{Pertumbuhan Tanaman Kangkung}

Pertumbuhan tanaman kangkung diamati dengan melakukan pengukuran tinggi tanaman, jumlah daun dan warna daun setiap minggu selama 8 minggu. (Tabel 2-4). Tabel 2. Pengaruh POC Rebung Bambu pada Tinggi Tanaman Kangkung (Minggu ke-8).

\begin{tabular}{ccccc}
\hline \multirow{2}{*}{ Perlakuan } & \multicolumn{3}{c}{ Tinggi Tanaman $(\mathrm{cm})$} & Rerata tinggi tanaman $(\mathrm{cm})$ \\
\cline { 2 - 4 } & U1 & U2 & U3 & \\
\hline P0 & 15 & 12 & 11 & $12,67^{\mathrm{a}}$ \\
P1 & 19 & 23 & 28 & $23,33^{\mathrm{b}}$ \\
P2 & 24 & 27 & 26 & $25,67^{\mathrm{b}}$ \\
P3 & 28 & 28 & 28 & $28,00^{\mathrm{b}}$ \\
P4 & 25 & 31 & 27 & $27,67^{\mathrm{b}}$ \\
\hline
\end{tabular}

Ket: angka yang diikuti dengan huruf yang berbeda menunjukkan beda nyata berdasarkan uji BNT $\mathrm{P}<0,05$.

Tabel 3. Pengaruh POC Rebung Bambu pada Jumlah Daun Kangkung (Minggu ke-8).

\begin{tabular}{ccccc}
\hline \multirow{2}{*}{ Perlakuan } & \multicolumn{3}{c}{ Jumlah daun (helai) } & Rerata jumlah daun (helai) \\
\cline { 2 - 4 } & U1 & U2 & U3 & \\
\hline P0 & 5 & 4 & 4 & $4,33^{\mathrm{a}}$ \\
P1 & 16 & 12 & 15 & $14,33^{\mathrm{b}}$ \\
P2 & 31 & 28 & 25 & $28,00^{\mathrm{c}}$ \\
P3 & 21 & 35 & 24 & $27,67^{\mathrm{c}}$ \\
P4 & 38 & 35 & 36 & $36,33^{\mathrm{d}}$ \\
\hline
\end{tabular}

Ket: angka yang diikuti dengan huruf yang berbeda menunjukkan beda nyata berdasarkan uji BNT $\mathrm{P}<0,05$. 
Tabel 4. Pengaruh POC Rebung Bambu pada Warna Daun Kangkung (Minggu ke-8).

\begin{tabular}{ccccc}
\hline \multirow{2}{*}{ Perlakuan } & \multicolumn{3}{c}{ Skala warna daun } & Rerata skala warna daun \\
\cline { 2 - 4 } & $\mathrm{U} 1$ & $\mathrm{U} 2$ & $\mathrm{U} 3$ & \\
\hline P0 & 2 & 2 & 3 & $2,33^{\mathrm{a}}$ \\
P1 & 3 & 4 & 3 & $3,33^{\mathrm{b}}$ \\
P2 & 4 & 4 & 4 & $4,00^{\mathrm{bc}}$ \\
P3 & 4 & 4 & 5 & $4,33^{\text {cd }}$ \\
P4 & 5 & 5 & 5 & $5,00^{\mathrm{d}}$ \\
\hline
\end{tabular}

Ket: angka yang diikuti dengan huruf yang berbeda menunjukkan beda nyata berdasarkan uji BNT $\mathrm{P}<0,05$.

Pengamatan terhadap pertumbuhan kangkung (tinggi tanaman, jumlah daun dan warna daun) menunjukkan adanya pengaruh yang berbeda nyata pada setiap perlakuan POC rebung bambu. Perlakuan terbaik diperoleh pada perlakuan P4 (pemberian POC sebanyak $200 \mathrm{ml}$ ) menunjukkan pertumbuhan tinggi tanaman $27,67 \mathrm{~cm}$, jumlah daun 36,33 helai dan warna daun dengan skala 5. Hal ini disebabkan tingginya kandungan nitrogen pada POC rebung bambu. Menurut Salisbury \& Ross (1995), fungsi nitrogen sangat esensial sebagai bahan penyusun asam-asam amino, protein dan klorofil yang penting dalam proses fotosintesis dan penyusunan komponen inti sel yang menentukan kualitas dan kuantitas hasil tanaman. Semakin banyak jumah klorofil yang tersedia di daun, menyebabkan pigmen warna hijau semakin pekat dan hasil fotosintesis juga meningkat. Kandungan klorofil yang cukup dapat membentuk atau memacu pertumbuhan tanaman terutama merangsang organ vegetatif tanaman. Pembentukan akar, batang dan daun terjadi dengan cepat jika persediaan makanan yang digunakan untuk proses pembentukan organ vegetatif tersebut dalam keadaan atau jumlah yang cukup sehingga unsur nitrogen sangat diperlukan dalam pembentukan organ baru khususnya daun tanaman (Marliani, 2011).

Rebung bambu juga mengandung giberelin sebagai salah satu zat pengatur tumbuh yang dapat merangsang pertambahan panjang antar ruas tanaman, sehingga tanaman terlihat lebih tinggi. Giberelin juga memacu pembelahan sel pada tumbuhan. Meskipun dalam penelitian ini tidak dilakukan pengukuran kandungan giberelin pada POC rebung bambu, namun diduga masih terdapat kandungan giberelin yang juga merangsang penambahan tinggi tanaman.

\section{KESIMPULAN}

Pemberian POC rebung bambu berpengaruh secara nyata terhadap tinggi tanaman, jumlah daun dan warna daun tanaman kangkung. Pemberian POC rebung bambu yang paling baik dalam meningkatkan pertumbuhan tanaman kangung (Ipomea reptans Poir) yaitu pada perlakuan P4 (pemberian POC $200 \mathrm{ml}$ ) yang menunjukkan pertumbuhan rata-rata tinggi tanaman $27,67 \mathrm{~cm}$, jumlah daun 36,33 helai dan warna daun dengan skala 5 .

BIOLOGI SEL (VOL 7 NO 1 EDISI JAN-JUL 2018 ISSN 2252-858X/E-ISSN 2541-1225) PAGE 47 


\section{SARAN}

Penggunaan POC rebung bambu dapat digunakan untuk meningkatkan pertumbuhan vegetatif pada tanaman, sehingga disarankan pada petani untuk menggunakan POC rebung bambu sebagai pengganti pupuk kimia. Budidaya tanaman menggunakan metode hidroponik juga dapat dilakukan dalam skala rumah tangga dengan memanfaatkan bahan organik yang tersedia di lingkungan sekitar.

\section{DAFTAR PUSTAKA}

Harjadi, S.S \& K. Suketi. 1999. Pengaruh Saat Pemanenan terhadap Produktivitas dan Kualitas Produksi empat Varietas Kangkung Darat. Bul. Agr. XVII (1) : 31-44.

Kencana, P.K.D. 1992. Pengaruh Umur Simpan dan Bagian Potongan pada Dua Jenis $R$ ebung terhadap Kualitas Rebung Kalengan. Tesis. Bogor: Program Pascasarjana. Institut Pertanian Bogor.

Lingga, P. 2005. Hidroponik Bercocok Tanam Tanpa Tanah. Jakarta: Penebar Swadaya. Marliani, V.P. 2011. Analisis Kandungan Hara N dan P serta Klorofil Tebu Transgenik IPB 1 yang di Tanam di Kebun Percobaan PG Djatiroto, Jawa Timur. Bogor: Faperta Institut Pertanian Bogor.

Marlina, I. S., Tryono, \& A. Tusi. 2015. Pengaruh Media Tanam Granul dari Tanah Liat terhadap Pertumbuhan Sayuran Hidroponik Sistem Sumbu. Jurnal Teknik Pertanian Lampung 4(2) : 143-150.

Mas'ud, H. 2009. Sistem Hidroponik dengan Nutrisi dan Media Tanam Berbeda terhadap Pertumbuhan dan Hasil Selada. Media Litbang Sulteng 2 (2) : 131- 136.

Rukmana, R. 1994. Kangkung. Yogyakarta: Kanisius

Salisbury, F.B. \& C.W. Ross. 1995. Fisiologi Tumbuhan Jilid I. Bandung: ITB Press.

Sawasemariai, A. M. 2012. Respon Pertumbuhan Hasil Tanaman Kangkung Darat terhadap Pemberian Pupuk Indorit. Sentrafoliar dan Indomess. Skripsi. Papua: Jurusan Budidaya Pertanian. Fakultas Pertanian dan Teknologi Pertanian. Universitas Negeri Manokwari.

Taufik, M. 2012. Strategi Pengembangan Agribisnis Sayuran di Sul-Sel. Jurnal Litbang Pertanian 31(2) : 43-50. 